\title{
保存的治療単独で救命し得た気腫性尿路感染症の 2 例
}

\begin{tabular}{|c|c|c|c|c|c|c|c|}
\hline 東 & 祥嗣 ${ }^{1)}$ & 中村 & 茂樹1) & 大島 & 一浩 ${ }^{1)}$ & 岩永 & 直樹1) \\
\hline 平山 & 達朗 ${ }^{1)}$ & 梶原 & 俊毅1) & 高園 & 貴弘 ${ }^{1)}$ & 宮崎 & 泰可 ${ }^{11}$ \\
\hline 泉川 & 公- ${ }^{11}$ & 桝原 & 克紀 ${ }^{2)}$ & 田代 & 隆良 ${ }^{3)}$ & 河野 & 茂 \\
\hline
\end{tabular}

(平成 26 年 4 月 23 日受付)

(平成 26 年 7 月 10 日受理)

Key words : emphysematous pyelonephritis, emphysematous cystitis

\section{序文}

気腫性尿路感染症は泌尿器科的緊急疾患の一つで, 容易に敗血症性ショックを来たす極めて予後不良な重 症感染症である．従来は，予後の改善には迅速な腎摘 出術や外科的ドレナージが必須と考えられていたが, 術後の腎機能の増悪や QOL の低下が認められること も少なくない，そのため近年では，状況に応じて可能 な限り腎・泌尿器機能の温存を目指す保存的治療に関 する報告が認められるようになった，今回我々は，抗 菌薬投与を中心とした保存的治療のみで救命し得た気 腫性尿路感染症の 2 症例を経験したので，文献的考察 を加えて報告する.

症例 $1: 69$ 歳, 男性.

主訴：四肢のしびれ，意識障害.

現病歴：間質性肺炎の診断でプレドニゾロン（12.5 $\mathrm{mg} /$ 日）にて外来内服加療中であった，四肢のしびれ 感や意識障害を主訴に近医受診。血圧低下と炎症反応 の著明な充進を認め, 敗血症性ショックを疑われ，当 院に緊急入院となった.

既往歴：糖尿病．排尿障害なし。

生活歴：喫煙 10 本/日 $\times 55$ 年, 飲酒; 日本酒 $3 \sim 4$ 合/日.

入院時身体所見: 身長 $177 \mathrm{~cm}$, 体重 $84.2 \mathrm{~kg}$, BMI $29.4 \mathrm{~kg} / \mathrm{m}^{2}$, 体温 $38.1^{\circ} \mathrm{C}$, 脈拍 110 回/分, 血圧 $44 / 31$ $\mathrm{mmHg}$, 呼吸数 12 回/分, $\mathrm{SpO}_{2} 97 \%$ (nasal $3 \mathrm{~L} / \mathrm{min}$ ), 心音・呼吸音正常, 肋骨脊柱角に吒打痛（右>左）あ り，尿閉なし。

神経学的所見 : JCSII-10, 構音障害あり.

入院時検查所見 (Table 1) : 未梢血白血球数 32,900

別刷請求先 : ( $=852-8501)$ 長崎市坂本 1-7-1 長崎大学病院第二内科 中村 茂樹
$/ \mu \mathrm{L}, \mathrm{CRP} 5.12 \mathrm{mg} / \mathrm{dL}$, プロカルシトニン $85.37 \mathrm{ng} / \mathrm{mL}$ と高度上昇を認めた，尿検査（沈渣）では白血球が著 明に増加し, 尿グラム染色では好中球によるグラム陰 性桿菌の領食像を多数認めた。

微生物学的検查: 2 七ットの血液培養, 尿培養より ESBL (extended-spectrum $\beta$-lactamase) 産生大腸菌 を分離.

画像所見：腹部 X 線写真（臥位）で左腎に相当す る部分にガス像を認めた。腹部 CT (Fig. 1) では両 側腎腫大, 左側の腎孟と腎実質, 尿管内にガス像を認 め, 腎孟，尿管はやや拡張している。 また, 腎周囲の 脂肪織の濃度上昇も伴って抢り周囲組織への炎症の波 及が疑われた，尿路結石なし．

入院後経過（Fig. 2) : 気腫性腎孟腎炎による敗血 症性ショックが疑われたため, 大量輸液と循環作動薬 の投与により循環動態の安定化を図った. 経験的抗菌

Table 1 Laboratory findings on admission

\begin{tabular}{|c|c|c|c|}
\hline \multicolumn{2}{|l|}{$\mathrm{CBC}$} & \multicolumn{2}{|c|}{ Biochemistry } \\
\hline WBC & $32,900 / \mu \mathrm{L}$ & $\mathrm{TP}$ & $5.2 \mathrm{~g} / \mathrm{dL}$ \\
\hline Stab & $5 \%$ & Alb & $2.3 \mathrm{~g} / \mathrm{dL}$ \\
\hline Seg & $91 \%$ & BUN & $29 \mathrm{mg} / \mathrm{dL}$ \\
\hline Eos & $0 \%$ & Cre & $2.12 \mathrm{mg} / \mathrm{dL}$ \\
\hline Baso & $0 \%$ & AST & $17 \mathrm{IU} / \mathrm{L}$ \\
\hline Mono & $0 \%$ & ALT & $19 \mathrm{IU} / \mathrm{L}$ \\
\hline Lympho & $4 \%$ & $\mathrm{LDH}$ & $216 \mathrm{IU} / \mathrm{L}$ \\
\hline $\mathrm{RBC}$ & $4.14 \times 10^{6} / \mu \mathrm{L}$ & $\gamma \mathrm{GTP}$ & $120 \mathrm{IU} / \mathrm{L}$ \\
\hline $\mathrm{Hb}$ & $12.3 \mathrm{~g} / \mathrm{dL}$ & $\mathrm{CK}$ & $85 \mathrm{IU} / \mathrm{L}$ \\
\hline \multirow[t]{2}{*}{ Plt } & $17.9 \times 10^{4} / \mu \mathrm{L}$ & $\mathrm{Na}$ & $134 \mathrm{mEq} / \mathrm{L}$ \\
\hline & & $\mathrm{K}$ & $3.3 \mathrm{mEq} / \mathrm{L}$ \\
\hline \multicolumn{2}{|c|}{ Blood gas analysis $\left(\mathrm{O}_{2}\right.$ : $3 \mathrm{~L}$ mask $)$} & $\mathrm{Cl}$ & $95 \mathrm{mEq} / \mathrm{L}$ \\
\hline $\mathrm{pH}$ & 7.368 & CRP & $5.12 \mathrm{mg} / \mathrm{dL}$ \\
\hline $\mathrm{pCO}_{2}$ & 36.7 Torr & $\mathrm{PCT}$ & $85.37 \mathrm{ng} / \mathrm{mL}$ \\
\hline $\mathrm{pO}_{2}$ & 117.0 Torr & GLU & $282 \mathrm{mg} / \mathrm{dL}$ \\
\hline $\mathrm{HCO}_{3}{ }^{-}$ & $20.6 \mathrm{mmol} / \mathrm{L}$ & HbAlc & $9.1 \%$ \\
\hline
\end{tabular}


Fig. 1 Abdominal radiograph on admission.

White arrow indicates the gas within the left kidney (a). Abdominal CT on admission (b, c).

White arrows indicate the gas within the left kidney and the urinary duct, respectively.
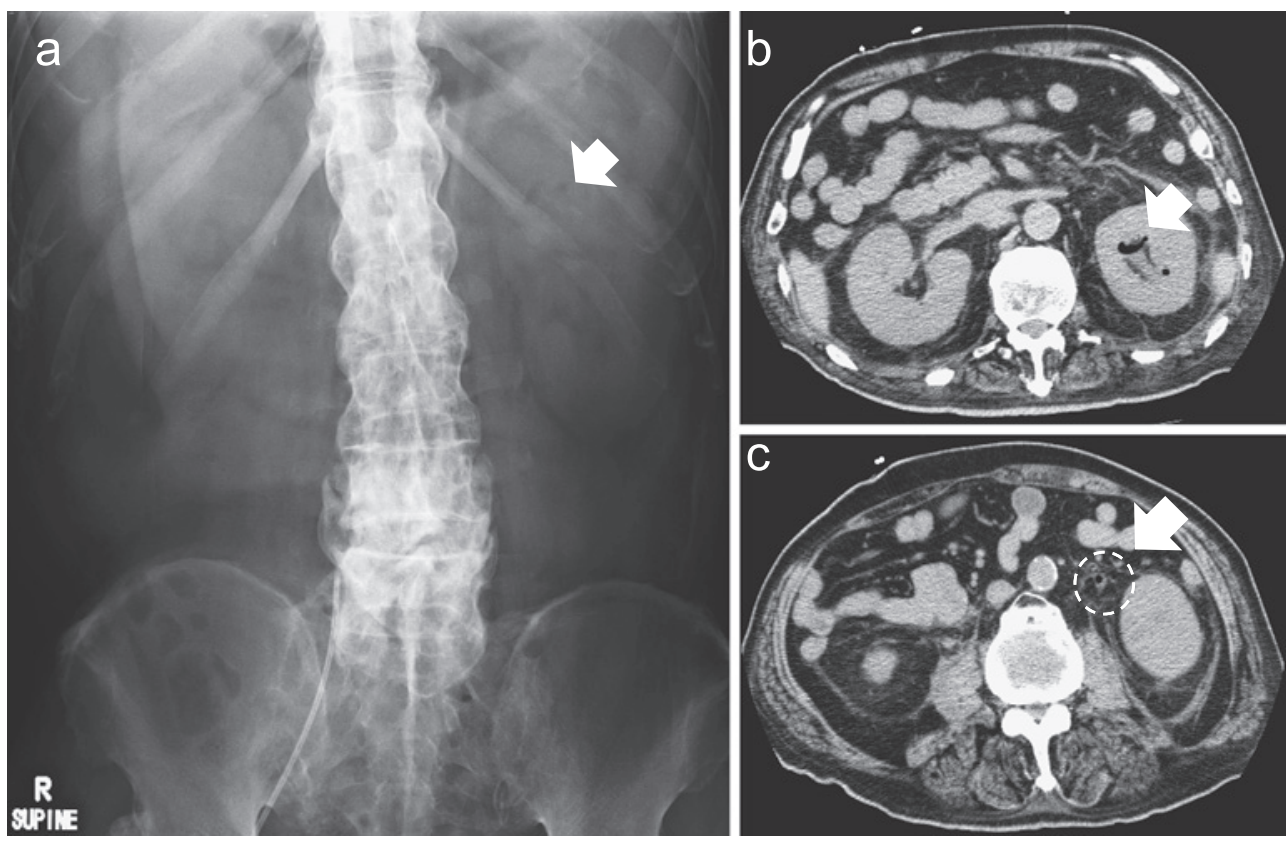

Fig. 2 Clinical course after admission.

DOA: Dopamine, NA: Noradrenalin, MEPM: Meropenem, IVIG: Intravenous immunoglobulin, eGFR: estimated glomerular filtration rate

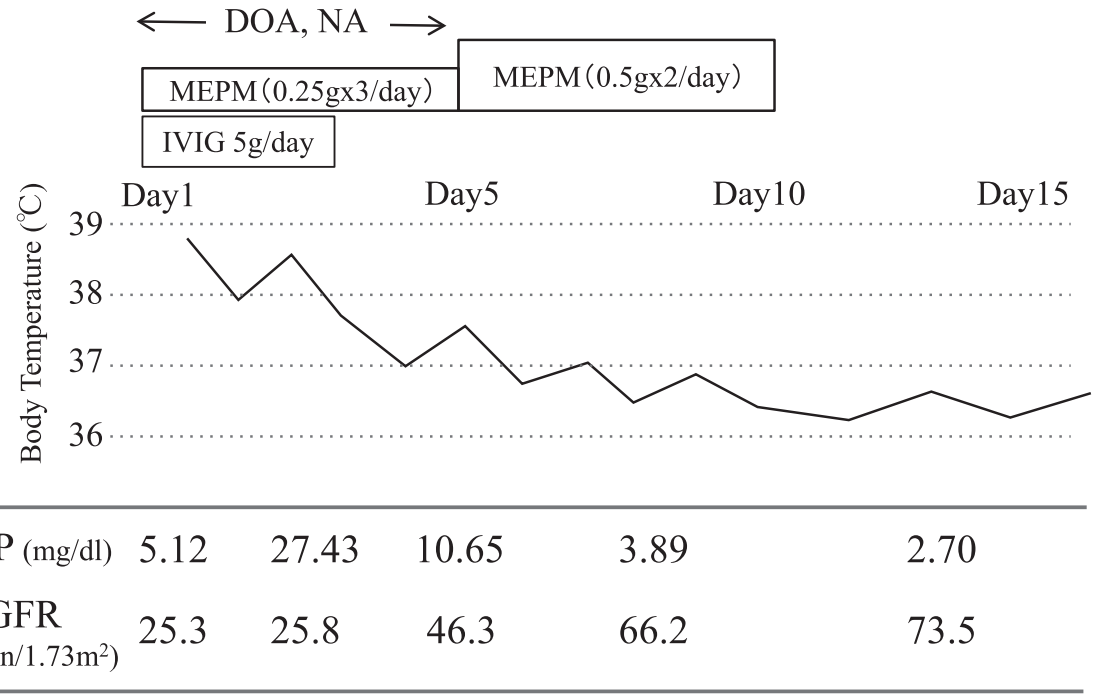

化学療法として ESBL 産生グラム陰性菌を考慮しメ ロペネム $(0.25 \mathrm{~g} /$ 回 $\times 3 /$ 日 $)$ 点滴静注を開始した。重 症感染症であるため $\gamma$ クグロブリン $(5 \mathrm{~g} /$ 日）点滴静注 も併用した。治療開始 3 日目に解熱傾向を認め, 循環 動態も安定化した. 第 11 病日に抗菌薬は中止可能と なり，腹部 CT では両腎腫大，腎実質内のガス像腎周 囲脂肪織の濃度上昇は消失していた。

症例 $2: 79$ 歳, 女性.

主訴：血尿.
現病歴：膜性腎症に対しプレドニゾロン $(18.5 \mathrm{mg} /$ 日）で外来内服加療中であった。約 3 週間前より肉眼 的血尿が出現したため当院へ紹介受診となった.

既往歴：膜性腎症, 発作性心房細動, 気管支拡張症, 糖尿病. 排尿障害なし.

生活歴：特記事項なし.

入院時身体所見：身長 $158 \mathrm{~cm}$, 体重 $54.1 \mathrm{~kg}$, BMI $21.7 \mathrm{~kg} / \mathrm{m}^{2}$, 体温 $36.3^{\circ} \mathrm{C}$, 脈拍 105 回 $/$ 分, 不整, 血圧 $74 / 40 \mathrm{mmHg}$, 呼吸数 13 回/分, $\mathrm{SpO}_{2}$ 94\% (room air), 
Table 2 Laboratory findings on admission

\begin{tabular}{|c|c|c|c|}
\hline \multicolumn{2}{|l|}{$\mathrm{CBC}$} & \multicolumn{2}{|c|}{ Biochemistry } \\
\hline WBC & $17,900 / \mu \mathrm{L}$ & $\mathrm{TP}$ & $5.0 \mathrm{~g} / \mathrm{dL}$ \\
\hline Stab & $7 \%$ & Alb & $2.7 \mathrm{~g} / \mathrm{dL}$ \\
\hline Seg & $93 \%$ & BUN & $64 \mathrm{mg} / \mathrm{dL}$ \\
\hline Eos & $0 \%$ & Cre & $1.80 \mathrm{mg} / \mathrm{dL}$ \\
\hline Baso & $0 \%$ & AST & $23 \mathrm{IU} / \mathrm{L}$ \\
\hline Mono & $0 \%$ & ALT & $25 \mathrm{IU} / \mathrm{L}$ \\
\hline Lympho & $0 \%$ & $\mathrm{LDH}$ & $216 \mathrm{IU} / \mathrm{L}$ \\
\hline $\mathrm{RBC}$ & $3.39 \times 10^{6} / \mu \mathrm{L}$ & $\gamma \mathrm{GTP}$ & $64 \mathrm{IU} / \mathrm{L}$ \\
\hline $\mathrm{Hb}$ & $10.2 \mathrm{~g} / \mathrm{dL}$ & CK & $35 \mathrm{IU} / \mathrm{L}$ \\
\hline \multirow[t]{2}{*}{ Plt } & $25.5 \times 10^{4} / \mu \mathrm{L}$ & $\mathrm{Na}$ & $130 \mathrm{mEq} / \mathrm{L}$ \\
\hline & & $\mathrm{K}$ & $2.6 \mathrm{mEq} / \mathrm{L}$ \\
\hline \multicolumn{2}{|c|}{ Blood gas analysis (room air) } & $\mathrm{Cl}$ & $92 \mathrm{mEq} / \mathrm{L}$ \\
\hline $\mathrm{pH}$ & 7.446 & CRP & $0.54 \mathrm{mg} / \mathrm{dL}$ \\
\hline $\mathrm{pCO}_{2}$ & 37.8 Torr & $\mathrm{PCT}$ & $0.173 \mathrm{ng} / \mathrm{mL}$ \\
\hline $\mathrm{pO}_{2}$ & 85.0 Torr & GLU & $247 \mathrm{mg} / \mathrm{dL}$ \\
\hline $\mathrm{HCO}_{3}^{-}$ & $25.6 \mathrm{mmol} / \mathrm{L}$ & HbAlc & $6.6 \%$ \\
\hline
\end{tabular}

心音・呼吸音正常, 四肢冷汗軽度あり, 浮腫なし. 神 経学的所見正常.

入院時検査所見 (Table 2) : 未梢血白血球数 17,900 $/ \mu \mathrm{L}$ と増加し, $\mathrm{CRP}$ は $0.54 \mathrm{mg} / \mathrm{dL}$ と軽度上昇認めた。 尿検査で白血球数が著明に増加しており，尿グラム染 色では好中球によるグラム陰性桿菌の貪食像が多数認 められた。

微生物学的検査：尿培養で ESBL 産生大腸菌が分 離. 2 セットの血液培養陰性.

入院時画像所見：腹部 CT (Fig. 3) では骨盤内に 膀胱を取り巻くようにガス像を認めた．両腎には明ら かな異常は認めない.

入院後経過 : 気腫性膀胱炎に伴う敗血症性ショック と診断し, 大量輸液と循環作動薬を投与し循環動態の 維持を図った。尿グラム染色でグラム陰性桿菌の貪食 像が認められたものの, 尿より MRSAの分離歴があ ることを考慮し, 経験的抗菌化学療法としてメロペネ ム $(0.5 \mathrm{~g} /$ 回 $\times 2 /$ 日 $)$ とバンコマイシン $(1 \mathrm{~g} /$ 回/日 $)$ の 点滴静注を行った. 尿培養の結果, ESBL 産生大腸菌 が分離されたため, 第 6 病日にバンコマイシンは中止 し, 治療経過も良好であったためメロペネムは第 9 病 日に中止した．腹部 CT で認められた膀胱壁の著明な 気腫性変化もほぼ消失した。

\section{考察}

気腫性腎孟腎炎は腎内外または膀胱内にガスを産生 し，容易に敗血症性ショックやケトアシドーシスなど に進展し急激に悪化する．死亡率は 11～42\% と極め て高く, その予後不良因子として保存的加療, 血小板 減少, 意識障害, 急性腎機能障害, ショック状態など が報告されている ${ }^{1)}$. 本疾患に特徴的な尿路のガス産 生像は診断に極めて有用であるが, その発生機序とし て，(1)糖尿病により増加した組織内グルコースのガス
Fig. 3 Abdominal CT on admission showing air bubbles within the bladder wall (black arrows).

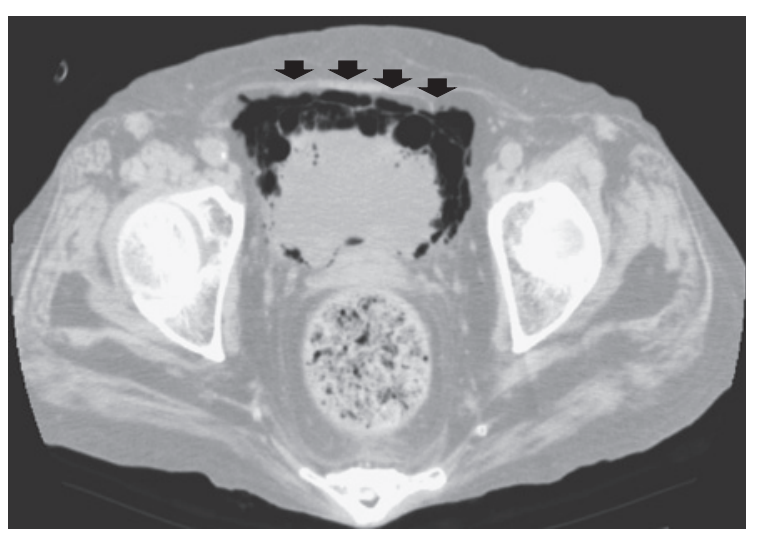

産生菌（嫌気性菌）による発酵分解，(2)組織中の循環 不全によって生じた壊死組織内の細菌増加によるグル コースの発酵分解などが考えられている

気腫性尿路感染症の発症には宿主因子も深く関与す ることが知られており, 糖尿病や悪性腫瘍の合併, 前 立腺肥大症などに由来する尿路閉塞との関連性も指摘 されている ${ }^{3)}$. Tseng らは多変量解析にて, 気腫性尿 路感染症は通常の尿路感染症に比へ，糖尿病患者と尿 路閉塞のある患者で有意に発症しやすく, 特にコント ロール不良（HbAlc>11\%）の糖尿病をリスク因子 として報告している ${ }^{4}$.

本症例のように保存的治療の適応を判断する上で腹 部 CT 所見が有用である. Huang ${ }^{5)} ら は \mathrm{CT}$ 所見に基 づき気腫性腎孟腎炎の重症度を class1〜 4 に分類し, 集合管もしくは腎実質内にガスが限局している class 1, class2 では保存的治療が可能であり, ガスが両側 性もしくは腎外に及ぶ class3, class4 ではリスク因子 （血小板減少, 急性腎障害, 意識障害, ショック）の 数が 2 個未満であれば保存的治療を，2 個以上であれ ば外科的治療の導入を推奨している.

気腫性尿路感染症の原因菌の $70 \%$ 以上が Escherichia coli (E. coli) であり, その他に Klebsiella pneumoniae, Proteus mirabilis, Aerobacter や Candidana albicns, Clostridum septicum などが報告されている ${ }^{6)}$. 日 本化学療法学会による成人複雑性尿路感染症のサーベ イランス (2008) では E. coli の約 5.1\% が ESBL 産生 菌であることが報告されている7). しかし本邦におけ る ESBL 産生 E. coli の分離率は近年, 尿路感染症を 中心に増加傾向にあるとの報告も認められており ${ }^{8)}$, 初 期抗菌薬の選択を行う際には十分注意する。欧州泌尿 器科学会では複雑性尿路感染症に対する適切な抗菌薬 選択について，推定原因菌のそれぞれの地域における 耐性パターンを考慮することが重要とした上で, 重症 の複雑性尿路感染症に対しては fluoroquinolone など 
広域抗菌薬の使用が推奨されている ${ }^{9)}$.

今回報告した 2 症例は，ともに基礎疾患として糖尿 病を認め, 来院時に多数の予後不良因子(急性腎障害, 意識障害, ショック）を認めていた. しかし症例 1 で はガスおよび膿瘍が腎実質に限局しており，腎外への 進展がなく腎実質の破壊もないためHuang の分類で Class 2 に分類された，そのため，まずは保存的治療 を選択し，治療抵抗性の場合に腎摘出などの外科的治 療を行う方針とした．感染コントロールのため経皮的 ドレナージの併用も泌尿器科と相談し検討したが，ド レナージを行うスペースがなく手技的に困難であった ため今回は施行されていない. 症例 2 では気腫性病変 は膀胱周囲に限局しており，気腫性腎孟腎炎の合併も なく，保存的治療を選択した． 2 症例ともに重症度評 価や予後不良因子の有無など病態の正確な把握を行 い, 保存的治療が可能と判断した. また, 積極的に CT 検査を行い比較的早期に気腫性尿路感染症と診断でき たことや地域の ESBL 産生菌分離状況を考慮し, 速 やかにカルバペネム系薬を中心とした強力な抗菌化学 療法を開始できたことも保存的治療のみで救命できた 要因と考えられた.

感染巣の摘出などの積極的な外科治療の併用は，重 症感染症の予後を改善する上で極めて重要な治療法の 一つであるが, 術後に著しい QOL の低下を引き起こ す場合がある．近年，抗菌化学療法や感染症の診断技 術は格段に進歩し, 迅速かつ強力な感染症治療の導入 が可能となった，気腫性尿路感染症のように，従来で は外科治療が推奨された重症感染症であっても，患者 背景や全身状態, 感染巣の進行状況などの正確な病態 把握が可能であれば，保存的治療を選択できる症例も 相当数存在するものと考えられる. 各診療科における 今後の臨床研究の進展とエビデンスの集積が待たれ る.

利益相反自己申告：申告すべきものなし

\section{文献}

1) Falagas ME, Alexiou VG, Glannopoulou KP, Siempos II : Risk factors for mortality in patients with emphysematous pyelonephritis: A metaanalysis. The Journal of urology $2007 ; 178$ : $880-5$.

2) Yang WH, Shen NC: Gas-forming infection of the urinary tract:an investigation of fermentation as a mechanism. J Urol $1990 ; 143: 960$-4.

3) Tsitouridis I, Michaelides M, Sidiropoulos D, Arvanity $\mathrm{M}$ : Renal emphysema in diabetic patients: CT evaluation. Diagnostic and Interventional Radiology $2010 ; 16: 221-6$.

4) Tseng C, Wu J, Wang M, Hor L, Ko Y, Huang $\mathrm{J}:$ Host and Bacterial Virulence Factors Predisposing to Emphysematous Pyelonephritis. American Journal of Kidney Diseases 2005 ; $46: 432-9$.

5) Huang JJ, Tseng C:Emphysematous pyelonephritis: clinicoradiological classification, management, prognosis and pathogenesis. Arch Intern Med $2000 ; 60: 797-805$.

6) Khaira A, Gupta A, Rana DS, Bhalla A, Khullar D : Retrospective analysis of clinical profile prognostic factors and outcomes of 19 patients of emphysematous pyelonephritis. Int Urol Nephrol 2009 ; 41:959-66.

7) Ishikawa K, Matsumoto T, Yasuda M, Uehara S, Muratani T, Yagisawa $\mathrm{M}$, et al. : The nationwide study of bacterial pathogens associated with urinary tract infections conducted by the Japanese Society of Chemotherapy. J Infect Chemother $2011 ; 17: 126-38$.

8）赤松紀彦, 柳原克紀, 松田淳一, 木下和久, 城 野 智, 脇川富美子, 他：長崎県における薬剂 耐性菌調査ネットワーク設立と耐性菌サーベイ ランス (2006 2009 年). 日本臨床微生物学雑誌 $2012 ; 22: 66$-71.

9) Grabe M, Bjerklund-Johansen T.E, Botto H, Cek M, Naber K.G, Pickard R.S, et al. : Guidelines on urological infections. European Assosiation of urology 2013. 
Two Cases of Emphysematous Urinary Tract Infections Successfully Treated with

Conservative Management

Yoshitsugu HIGASHI', Shigeki NAKAMURA ${ }^{11}$, Kazuhiro OSHIMA ${ }^{11}$, Naoki IWANAGA ${ }^{11}$, Tatsuro HIRAYAMA ${ }^{1}$, Toshiki KAJIHARA ${ }^{1}$, Takahiro TAKAZONO ${ }^{1)}$, Taiga MIYAZAKI', Koichi IZUMIKAWA ${ }^{1)}$, Katsunori YANAGIHARA ${ }^{2)}$, Takayoshi TASHIRO ${ }^{3)} \&$ Shigeru KOHNO ${ }^{1)}$

${ }^{1)}$ Second Department of Internal Medicine and ${ }^{2)}$ Department of Laboratory Medicine, Nagasaki University Hospital, ${ }^{3}$ Department of Health Sciences, School of Medicine, Nagasaki University

Emphysematous urinary tract infection is a rare, fulminant complication that is characterized by the presence of gas in the pelvicaliceal system, renal parenchyma, perinephric tissues and retroperitoneum. Surgical resection is usually regarded as the treatment of choice, however several studies have shown the safety and efficacy of conservative management under the correct diagnosis and appropriate antibiotic administration. We herein report on two cases of emphysematous urinary tract infection, pyelonephritis and cystitis infected with ESBL-producing Eschrerichia coli, complicated with diabetic mellitus which were successfully treated with conservative treatment.

〔J.J.A. Inf. D. $88: 861 \sim 865,2014 〕$ 